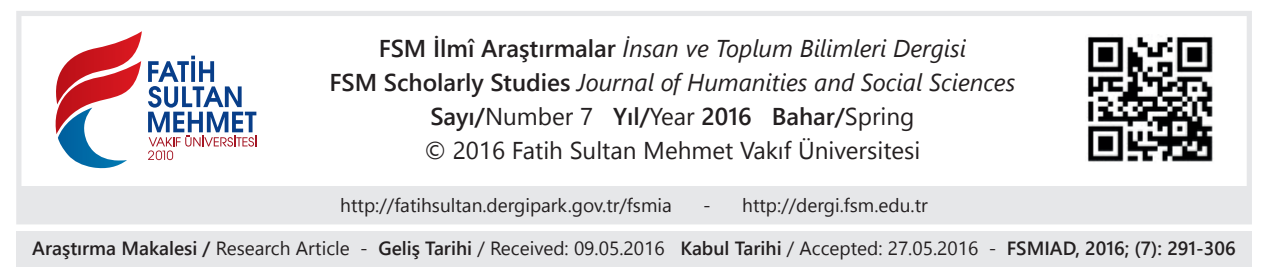

\title{
Türkiye'de Türk Sosyoloji Tarihi Üzerine Yapılmış Çalışmalar - Bibliyografya ve Değerlendirme -
}

ilyas Sucu*

\section{$\ddot{O} \mathbf{z}$}

Türkiye'de sosyolojinin -sadece akademideki tarihi bile dikkate alındığında- yüz yılı aşkın bir tarihi vardır. Sosyolojinin Batı'dan ithali ile başlayan bu süreçte, Batı'dan yapılan sistematik aktarımlar, oluşan farklı yaklaşım/ekoller, açılan kürsüler/bölümler, akademi dışı kurumsallaşmalar, süreli yayınlar, telif/tercüme eserler, yüzlerce sosyolog ve binlerce tezle birlikte bir Türk sosyoloji tarihi külliyatından bahsetmek mümkün hale gelmiş̧ir. Bu külliyatın zamanla genişlemesi, kendisi üzerine de bir alanın oluşmasını olanaklı kılmıştır. Şimdilerde birçok üniversitenin lisans ve lisansüstü programlarında kendisine yer bulan Türk Sosyoloji Tarihi ve benzer adlarla açılan dersler, konunun önemini ortaya koyacak niteliktedir. Türkiye'de kendi sosyoloji tarihimizi ele alan birçok çalışma mevcuttur. Bu çalışmada amaçlanan ise Türkiye'de, Türk Sosyoloji Tarihi ile ilgili şu ana kadar yapılmış tüm çalışmaları (kitap, süreli yayın, bibliyografya, derlemeler, makaleler) bütüncül olarak ele almaktır. Türk sosyolojisinin 100. yılının çeşitli yazınsal faaliyetlerle ele alındığı bir dönemde, bu külliyat üzerine yapılmış tarihi çalışmaları değerlendirmek Türk sosyolojisinin birikimi adına umut verici olacaktır.

Anahtar Kelimeler: Türk sosyoloji tarihi, Türkiye'de sosyoloji, Türk sosyologları.

\section{Studies of Turkish History of Sociology in Turkey - Bibliography and Assessment -}

\begin{abstract}
Sociology has a history over a hundred years in Turkey, even only considering the history of the academy. In this process, which began with importation of sociology from west, with systematic transfers made from the West, different approaches / schools occurred, chairs / departments opened, non-academic institutionalizations, periodicals, translated works, hundreds of sociologist and thousands of thesis, now it is possible to mention the corpus of Turkish sociology history. With the enlargement of this corpus in time, also enabled a field onto itself. Courses offered in undergraduate and graduate programs of many universities with the name of Turkish Sociology History or with sim-
\end{abstract}

* Yrd. Doç. Dr., Ondokuz Mayıs Üniversitesi Fen-Edebiyat Fakültesi Sosyoloji Bölümü, Samsun/Türkiye, ilyas.sucu@omu.edu.tr 
ilar names are showing the importance of the issue. There are many works in Turkey addressing our own sociology history. The aim of this study is investigating all studies (books, periodicals, bibliographies, reviews, articles) with a totalitarian approach. In this 100th anniversary of the Turkish sociology period dealt with various literary activities, assess the work done on the date of this corpus will be promising on behalf accumulation of Turkish sociology.

Keywords: Turkish history of sociology, sociology in Turkey, Turkish sociologists. 


\section{Giriş}

Sosyoloji eğer toplumla ilgili bilgilerimize verdiğimiz isimlendirmeyse, sosyolojinin tarihini toplumun tarihiyle birlikte başlatmak kaçınılmazdır. Fakat burada, 'sosyoloji', Aydınlanma temelli bilim anlayışının bir disiplinini; 'toplum' da, endüstri ve Fransız devrimleriyle birlikte yeni bir insan birlikteliği biçimini tanımladığından, bu yeni disiplinin tarihi ancak 19. yüzyıldan itibaren izlenebilmektedir. Batı sosyolojisi G. Vico, Montesquieu, S. Simon'u vb. ancak öncü olarak kabul etmekte ve sosyoloji disiplinini A. Comte'la birlikte başlatmaktadır. Ülkemize sosyoloji disiplininin girişi ise Batılılaşma ile birlikte olduğu için, gerçekte rahatlıkla kendi 'toplumbilim' tarihimizden sayabileceğimiz tarihçiler, siyasetnameler ve önemli bazı isimler atlanarak, sosyoloji tarihimiz doğrudan Batı sosyolojisiyle temas üzerinden başlatılmıştır.

Ziya Gökalp'in Darülfünun'da ilk sosyoloji dersini verdiği tarih olan 1914 yılı, ülkemizde sosyolojinin akademik tarihinin başlangıcı olarak kabul edilmektedir. Bu bağlamda ülkemizde sosyolojinin sadece akademide bile yüzy1lı aşan bir tarihi mevcuttur. Akademi dışı unsurları dikkate aldığımızda ise -örneğin Ali Süavi'nin Frederic Le Play'den bahsedişi 1870'lerdedir- bu tarihi birikim, yüz elli yıla varmak üzeredir. İsimleri, ekolleri, kurumları, telif/tercüme eserleri ve süreli yayınlarıyla birlikte bugün karşımızda olan bu birikim, doğal olarak kendi tarihini kendisine konu edinecek bir kapsama ulaşmış bulunmaktadır.

Kendi tarihini kendisine konu edinme, Türk sosyolojisi için neden önemlidir? Bu sorunun en kısa ve yalın cevabı, Türk sosyolojisinin doğru bir istikamet üzere olabilmesi içindir. Sosyoloji yapmamızdaki amaç Türk toplum çıkarlarının savunulmasıysa, bu ancak Türk sosyolojisi içerisinde, kimin hangi söze sahip olduğunu bilmekle başlar. Taklitçi sosyologlar da dâhil olmak üzere, bu ülkenin sorunları önünde düşünen, sözü olan her sosyolog/düşünür ve çalışması önemlidir, önemsenmelidir.

Bu çalışmada amaçlanan tam olarak budur: Yüz elli yıla yaklaşan Türk sosyoloji serüvenini kendisine konu edinmiş çalışmaları sınıflamak ve değerlendirmektir. Türk sosyoloji tarihi çalışmaları, alanında kılavuz çalışmalardır. Derine/ ayrıntıya inmeden önce kuşbakışı bir yaklaşımla toplum gerçeğimiz üzerine söylenmiş sözlerin, ortaya konmuş ürünlerin bütünsel anlaşılmasını sağlar. Parça-bütün diyalektiğinden hareketle, önce bütünün anlaşılmasına gayret eder. Aynı zamanda da ilim dalındaki gelişme seyrini, daha da önemlisi mevcut ilmin istikametinin anlaşılmasına katkı sunar. Dolayısıyla zaruri ve oldukça faydalı bir alandır. Bu çalışmanın gayreti de bu yönde olacak ve Türk sosyoloji tarihi ile ilgili -ulaşılabilen - tüm çalışmalar tanıtılacak ve değerlendirilecektir. Bu çalışmanın bir diğer faydasının ise üniversite lisans ya da lisansüstü müfredatlarında gittikçe daha çok yer verilmeye başlanan bu minvaldeki derslere, kaynakça teşkil etmesi bakımından mütevazı bir katkı sağlayacağının umulmasıdır. 


\section{Türk Sosyoloji Tarihi Üzerine Yapılmış Çalışmalar}

$\mathrm{Bu}$ çalışmada izlenecek metot şu şekildedir; çeşitli sınıflandırmalar altında bu konu ile ilgili yapılmış çalışmalar tarihsel önceliğine göre verilecek, içerik ve önemlerine dair kısa değerlendirmeler yapılacaktır. Çalışmaların tam künyeleri ise metnin sonunda, konu ile ilgili seçilmiş kaynakça kısmında verilecektir.

\section{Türk Sosyoloji Tarihi ile İlgili Yazılmış Kitaplar}

Türk sosyoloji tarihi ile ilgili ele alacağımız ilk kitap Baykan Sezer'in Türk Sosyolojisinin Ana Sorunları olacaktır. Sezer'in bu kitabı aslında klasik sosyoloji tarihi kitaplarının kapsamına uzak düşmesine rağmen, Türk sosyolojisiyle ilgili kılavuz bir çalışma olması hasebiyle burada kendisine yer bulmuştur. Kılavuz sıfatı, bu kitap için yanlış ya da abartı değil sıfatın temsili ve teslimidir. Kitap, sosyolojinin özelde de Türk sosyolojisinin tarihle, Türk/Osmanlı tarihiyle birlikte kavranılması ve ancak bu şekilde bugüne dair bir söz söyleyebileceği iddiasındadır. Türk sosyolojisi eğer Türk toplum gerçeğini anlama ve açıklama gayretiyse, bu ancak Türk tarihi ile birlikte mümkündür. Türk sosyolojisi ancak bu şekilde şahsiyet edinebilir. Sezer, bu eserinde bir taraftan Türk sosyolojisinin sorunlar1nı ortaya koyarken diğer taraftan da yine Türk sosyolojisinin "kendi gelenek ve yöntemlerini kurmak zorunda olduğunu" ifade etmekte ve ancak o zaman sosyolojinin "Türk toplumuna ışık tutabileceğini" belirtmektedir. Son olarak Sezer, bu kitabında öncelikle Türk toplumu için önerilen kuramları eleştirel bir tarzda ele almakta, Türk toplumunun mevcut sorunlarını incelemekte ve kendi sosyolojik yöntemini ortaya koyarak Türk toplum gerçeğini ve sorunlarını tarihsel bir düzlemde yeniden tartışmaktadır. Dolayısıyla -bize göre-Türk Sosyolojisinin Ana Sorunları kitabı, Türk sosyoloji tarihi okumaları için, yerli ve tutarlı bir bakış açısı sağlayan kılavuz bir kitaptır.

İstanbul Üniversitesi (İ.Ü.) Edebiyat Fakültesi Sosyoloji Bölümü’nün 1989 tarihinde düzenlemiş olduğu İ.Ü. Sosyoloji Bölümü'nün Kuruluşunun 75. Yılı sempozyumunda sunulan tebliğlerin İsmail Coşkun tarafindan derlenmesiyle ortaya çıkan 75. Yılında Türkiye'de Sosyoloji, ele alacağımız ikinci kitaptır. Ziya Gökalp'ın 1914'de ismi daha sonra İstanbul Üniversitesi olacak Darülfünun'da ilk sosyoloji dersini vermesiyle başlayan Türk sosyolojisinin akademik serüveninin, yine aynı üniversitenin bölümü tarafından 75. yılına atfen yapılan bu organizasyon, tarihsel sürekliliğe yaptığı vurgu anlamında önemsenmelidir. Kitapta yerli ve yabancı birçok akademisyenin tebliği yer almaktadır. Baykan Sezer'in açılış konuşması metni dışında sunduğu iki tebliğiyle birlikte, dikkatimizi çeken diğer bir yazı ise İsmail Coşkun'un İ.Ü. Sosyoloji Bölümü'nün tarihini anlattığı tebliğidir. Kitapta ayrıca Şemsettin Günaltay, Ziya Gökalp ve Ziyaeddin Fahri Fındıkoğlu ile ilgili birer tebliğ metni de yer almaktadır. 
Türk sosyoloji tarihi deyince akla ilk gelen isimlerin başında kuşkusuz $\mathrm{H}$. Bayram Kaçmazoğlu gelmektedir. Akademik çalışma hayatının merkezi ilgisi olan Türk sosyoloji tarihi ile ilgili üç ciltlik yayınının dışında, bu konudaki makalelerinden oluşan dört kitabı daha mevcuttur. Türk Sosyoloji Tarihi I: Önkoşullar'da Kaçmazoğlu, "sosyolojinin Türkiye'ye hangi iç ve dış siyasal-toplumsal koşullarda geldiğini" anlamaya çalışmış, bu bağlamda endüstri devrimi gibi dış şartlardan Rus göçmenleri gibi iç şartlara, geniş bir yelpazede konuyu ele almıştır. Türk Sosyoloji Tarihi II: II. Meşrutiyetten Cumhuriyete başı11ğını taşıyan ikinci ciltte ise yazarın tüm çabası, belirttiği dönemde, ülkemizdeki sosyoloji ekollerini tanıtmaya yöneliktir. Özellikle Ziya Gökalp ve Prens Sabahaddin'e hacimli bir yer ayrılan bu ciltte ayrıca, Türk sosyolojisinde bir dönem etkin olmuş biyolojik, Marksist ve psiko-sosyal gibi sosyoloji ekolleri de ihmal edilmemiştir. Kaçmazoğlu, serinin üçüncü kitabı olan Türk Sosyoloji Tarihi III: Yeni Türkiye'de Sosyolojinin Düşünsel ve Kurumsal Temelleri'nde ise 1923/1924 başlayarak 1930'ların sonuna kadar Türk sosyoloji tarihi serüvenini sürdürmektedir. Bu kitabın kurgusu ise öne çıkan sosyologları tek tek ele almak değil, dönemin iç ve diş gelişmeleri, tartışmaları, konu alanlarına yönelik sosyologların getirdiği yorumları birlikte ele almak şeklindedir. Böylesi bir kurgunun ise, dönemi ve dönem tartışmalarını daha iyi anlama noktasında faydalı olacağ 1 kuşkusuzdur. Kaçmazoğlu'nun bahsi geçen bu üç ciltlik çalışması dışında konu ile ilgili makalelerini topladığı kitaplardan ilki, Türk Sosyoloji Tarihi Üzerine Araştırmalar başlığını taşımaktadır. Bu kitapta birçok Türk sosyoloğuyla ilgili bağımsız makaleler olduğu gibi, yazarın lisansüstü çalışmalarının kısaltılmış hali de mevcuttur. 1940-1950 ve 1950-1960 aras1 Türk sosyolojisini konu edinen bu makaleler, yazarın Türk sosyoloji tarihi kitaplarıyla birlikte düşünüldügünde tamamlayıcı bir öge konumundadırlar. Kaçmazoğlu'nun 2012 yılında yayınladığı Türk Sosyolojisinde Temalar başlıklı üç ciltlik çalışma ise, yazarın Türk Sosyoloji Tarihi Üzerine Araştırmalar kitabından, yani 1999 yılından sonra kaleme aldığı makalelerinin üç tema etrafında toplanmasından oluşmaktadır. Türkçülük, İslamcılık ve Muhafazakârlık; Kuram, Uygulama ve Sosyalizm ile Doğu-Batı Çatışması temalarından oluşan bu kitaplarda, sosyoloji tarihi ile ilgili kimi özel makaleler -örneğin, İstanbul Üniversitesi İktisat Fakültesi Sosyologlart: Sosyal Siyasetçi, Milliyetçi ve Bütüncü Sosyoloji Ekolü ya da Atatürk Üniversitesi Sosyoloji Bölümü Tarihi Üzerine Bir Deneme gibi- bulmak mümkündür.

Levent Ünsaldı ve Ercan Geçgin'in birlikte kaleme aldıkları Sosyoloji Tarihi: Dünya'da ve Türkiye'de başlığını taşıyan kitap, her ne kadar hacim olarak sosyolojinin dünyadaki gelişimine daha kapsamlı bir yer ayırmış olsa da, Türkiye'de sosyolojinin 1800'lerden 1940'lı yıllara kadar olan gelişimini bir düzenlilik içerisinde ele almıştır. Kitabın en özgün yanı belki de sosyolojinin hem Batı'daki doğuş ve kuruluş aşamalarını hem de aynı tarihlere denk gelen bu dönemde 
Türkiye'de sosyolojinin nasıl bir seyir izlediğini birlikte ele almış olmasıdır. Bu açıdan kitap, dünyada sosyolojinin gelişimiyle ülkemizdeki gelişimini birlikte ele almak isteyenler için öncelikli okunabilir.

Türk sosyoloji tarihi ile ilgili olarak kitap bahsinde ele alınacak kaynaklar bunlardır. Fakat birçok kitapta konuyu ilgilendiren yazınlar bulmak da mümkündür. Örneğin Kurtuluş Kayalı'nın Türk Düşünce Dünyasında Yol İzleri isimli çalışması, bir Türk sosyoloji tarihi çalışması olmamakla birlikte özellikle odaklandığ1 1940'lı yılların düşünce ortamı ve sosyologlarını kendisine konu edinmesiyle, dikkate değer bir çalışmadır. Üstelik Kayalı, bu çalışmasında söz konusu dönem ve sosyologlarını birbiriyle ilişkilendirerek ele almakta ve böylece dönemi anlamayı kolaylaştırmaktadır. Yine Şerif Mardin'in iki önemli çalışması, Yeni Osmanlı Düşüncesinin Doğuşu ile Jön Türklerin Siyasi Fikirleri, birer sosyoloji tarihi kitapları olmamakla birlikte hem sosyolojinin doğduğu/geliştiği düşünsel ortamı ele alması hem de Ali Süavi ve Ahmet Rıza gibi öncülerle, Abdullah Cevdet ve Prens Sabahaddin gibi sosyologların düşüncelerine derinlikli nüfuzuyla, Türk sosyoloji tarihinin başlangıç safhalarında yararlı olabilecek kitaplar olarak karşımızdadır.

\section{Türk Sosyologları Üzerine Yazılmış Kitaplar ve Derleme Çalışmalar}

Hilmi Ziya Üken'in 1966 yılında yayınladığı ve alanında hala aşılmamış kabul edilen Türkiye'de Çağdaş Düşünce Tarihi eseri, bu kısımdaki ilk kitabımızı oluşturacaktır. Tanzimat, Meşrutiyet ve Cumhuriyet dönemlerinin düşünce tarihinin detaylıca ve yorumlanarak ele alındığ 1 bu hem hacimli hem de nitelikli eser, övgüyü ziyadesiyle hak etmektedir. Bu eserde birçok düşünce ekolünün ve birçok düşünürün, gerek bağımsız başlıkta gerekse de düşünce tarihinin anlatıldığı bölümlerde ele alındığını görmek mümkündür. Batı ile ilk temaslardan başlayarak Genç Osmanlılara, pozitivizm hareketinden memleketçilik akımına kadar, yüzyı11 aşkın bir tarihi düşünce serüvenini ele alması bir yana, Ziya Gökalp ve Prens Sabahaddin'den Mümtaz Turhan ve Ziyaeddin Fahri Fındıkoğlu'na kadar, birçok sosyoloğu bu önemli kitapta müstakil başlıklar altında bulmak da mümkündür. Ülken'in konuya ve isimlerin birçoğuna tarihsel yakınlığının olması, kaynaklara vukufiyeti ve Türk sosyolojisinin en parlak zihinlerinden biri olması, bu kitabı değerli k1lan diğer hususlardır.

Hasan Ali Koçer'in Türk Sosyologları I adıyla 1975 yılında yayınladığı kitap, bu bölümde anlatılacak kitapların tipik bir örneğidir. Yazarın önsözde belirttiği üzere "kendi sosyal problemlerimizin çözümü için (...) kendi sosyologlarımı$z l$ ve düşüncelerini ögrenip ve onların doğru görüşlerini geliştirme"ye bir katk1 olarak kaleme aldığ 1 bu kitapta, altı sosyolog (A. Rıza, A. Şuayp, B. Nuri, M. Satı, P. Sabahaddin, C. Nuri) konu edinilmiştir. Kitabın girişinde ise sosyolojinin ülkemizdeki doğuşundan 1940’lı yıllara kadar olan gelişimi, önemli kaynakça- 
larla anlatılmıştır. Kitabın isminden hareketle birden çok cilt şeklinde planlandığı anlaşı1sa da, diğer metinler ya yazılamamış ya da -bizim tarafımızdan- kütüphanelerde bulunamamıştır.

Emre Kongar'ın Türk Toplumbilimcileri başlıklı iki ciltlik derlemesi, bu konuda en çok bilinen eserlerin başında gelmektedir. Bu kitabı öncekilerden ayıran özellik ise derleme olarak tasarlanmasıdır. Birinci cildi 1981, ikinci cildi 1988 yılında yayınlanan derlemede, toplamda on altı Türk sosyoloğu, alanında yetkin isimlerce kaleme alınmıştır. Birinci ciltte Emre Kongar'ın Türkiye'de Toplumbilimin Gelişmesi ve Yöntem Sorunu başlıklı giriş yazısı ile ikinci ciltte Zafer Toprak'ın Türkiye'de Toplumbilimin Doğuşu başlıklı giriş yazısı mevcuttur. Kitap bu haliyle kendinden sonraki bu tarz çalışmalar için de bir örneklik teşkil etmiştir.

Bu konudaki en kapsamlı çalışma M. Çağatay Özdemir tarafından derlenen Türkiye'de Sosyoloji: İsimler-Eserler başlığını taşıyan iki ciltlik yayındır. Özdemir'in deyişiyle, Türk Toplumbilimcileri eserinin yayınlanmasının üzerinden yirmi yıl geçmiş olmasına karşın bu eseri tamamlayacak bir ürünün ortaya çıkmaması, bu yeni eserin yayın nedenidir. Gerçekten de 2008 yılında yayınlanan bu derlemede, altmış sekiz Türk sosyoloğu ve düşünürüne yer verilmiş ve bu isimler ya alanında uzman kişilere ya da ele alınan sosyoloğun çalışma arkadaşı veya öğrencisine yazdırılmıştır. Burada ele alınan isimlerin bir diğer özelliği ise sadece akademideki sosyologların tercih edilmemiş olmasıdır. İktisat, tarih, edebiyat vb. alanlarda gerek akademi içinde gerekse akademi dışında çalışmalarını sürdüren, fakat ortak paydaları bu ülkenin sorunları olan, bunlara dair sözü olan düşünürlerin ele alınmış olmasıdır. Özdemir'in Sunuş kısmında kısa bir Türk sosyoloji tarihini de anlattığı bu eserin, alanda büyük bir boşluğu doldurduğunu ve belki de unutulmaya yüz tutmuş kimi isimleri tekrardan düşünce dünyamıza taşıdığını iddia etmek abartı olmayacaktır.

Ege Üniversitesi Sosyoloji Bölümü’nden Hale Okçay'ın bir grup doktora öğrencisini yönlendirerek hazırlattığı Türkiye'de Sosyolojinin Yüzyıllık Serüveni kitabı, örnek bir doktora dersi grubu çalışması olarak karşımızdadır. Kitapta ele alınan yirmi sosyolog, aynı dönemlerde sosyoloji yapan ikişerli gruplar şeklinde ele alınmıştır. Fakat bu anlamlı kurgu metne yansıtılamamış, ele alınan sosyologlar yine kendi düşünceleriyle bağımsız bir tarzda tanıtılmış, aynı dönemde ele alınmış olan diğer sosyolog ve düşüncesiyle bir eşleştirme-karşılaştırma yapılamamıştır. Fakat henüz doktora ders döneminde olan bu öğrenci yazarların, Türk sosyolojisini önemsemeleri ve bizzat yayın faaliyetine eşlik etmeleri takdire şayandır.

$\mathrm{Bu}$ bölümde ele alacağımız son eser, S. Hayri Bolay'ın, büyük bir emek verdiği anlaşılan ve birçok makalesini bizzat kendisinin yazdığ Tanzimattan Günümüze Türk Düşünürleri başlığını taşıyan ve toplamda yedi cilt-sekiz ki- 
taptan oluşan külliyattır. Bolay, sunuş yazısında düşünce tarihi yazma gerekçelerini sıralarken, Ülken'in nezaretinde hazırladığı lisans bitirme tezinde de Türk düşünce tarihinin özel bir alanını çalıştığını ve o tarihten bu yana, özellikle de yine Ülken'in burada da bahsi geçen kitabının yayınlanmasıyla bu alana daha da ilgi duyarak böyle bir çalışmayı kaleme aldığını ifade etmektedir. Amaçlanan ise Türk düşüncesinin zenginliği/derinliğini göstermeye bir katkıdır. Tanzimattan Günümüze Türk Düşünürleri külliyat1, siyasi, idari ve sosyal düşünce temsilcileri; bilimsel ve felsefi düşünce temsilcileri; ahlaki ve edebi düşünce temsilcileri ile dini ve tasavvufi düşünce temsilcileri şeklinde tema-ciltlere ayrılmıştır. Bolay'ın birçok makalesini bizzat kendisinin yazdığı bu külliyatta yine birden çok Türk sosyoloğunun da alanında uzman akademideki sosyologlar tarafından yazıldığı görülmektedir. Külliyattaki isimler belirli bir kronoloji takip edilerek yazılmış ve bu sayede düşünürlerin birbirlerinden nasıl etkilendikleri, hangi düşünürün hangi düşünürü takip ettiğini anlamak kolaylaşmıştır. Bu hacimli külliyat, yeni olması hasebiyle -yayın tarihi Ekim 2015'dir- tarafimızdan da yeterince incelenememiştir ve derinlikli bir şekilde tanıtılmaya muhtaçtır.

\section{Süreli Yayın Özel Sayıları}

Kimi süreli yayınlar, Türk sosyoloji tarihi ile ilgili özel sayılar çıkarmışlar ve bu sayede konuya verdikleri önemi göstermişlerdir. Bu yayınlardan önemli bir kısmı ise Türkiye'de sosyolojinin 100. yılı münasebetiyle yayınlanmıştır ve bu yazı kaleme alınırken hala çıkması planlanan yüzüncü yıl sayıları olduğu yazar tarafından bilinmektedir. Şimdi bu özel sayıları tek tek ele alalım.

Tarihsel kronolojiyi takip ederek ele alacağımız ilk süreli yayın özel sayısı Kültür Bakanlığı tarafından çıkarılan Milli Külttür Dergisi'dir. Derginin Nisan 1991 tarihli 83. sayıs1, Sosyolojimizin Sosyolojisi dosyasıyla yayınlanmış ve bir Türk sosyoloji geleneğinden söz edilip edilemeyeceğini kendisine konu edinmiştir. Akademideki birçok sosyoloğun gerek müstakil makale gerekse de kendilerine yöneltilen konu ile ilgili soruya verdikleri cevapla bu tartışmaya dâhil oldukları görülmektedir.

Toplumbilim Dergisi'nin Türk Toplumbilimi Özel Sayısı başlı̆̆ıyla Ekim 1993 'te yayınladığı 2. sayısı, bu özel yayınların ikincisidir. Hayatta olmayan birçok Türk sosyoloğunun bağımsız makalelerle konu edinildiği bu özel say1da, Mehmet Ö. Alkan'ın “II. Meşrutiyet'in Ilk Yarısında Toplumbilim (Sosyoloji) Yazını ve Toplumbilimsel Düşünce Üzerine Notlar" başlığını taşıyan önemli bir makalesi de bulunmaktadir.

Bilim ve Sanat Vakfı Türkiye Araştırmaları Merkezi tarafından çıkarılan Türkiye Araştırmaları Literatür Dergisi, 2008 yılında yayınladığı 11. sayısında, Türk Sosyoloji Tarihi'ni kendisine konu edinmiştir. Bu özel say1, Türk 
sosyolojisinde ön plana çıkmış kimi isimlerle ilgili kaleme alınmış müstakil makaleleri; köy, kentleşme, din vb. gibi sosyoloji alt disiplinlerinin Türk sosyolojisindeki gelişimini konu edinen çalışmaları; kimi önemli sosyologlarla yapılan röportajları ve sosyoloji ders/tarih kitapları, dergileri ve kongreleri üzerinden yapılan incelemeleri ile birlikte, belki de şu ana kadar yayınlanan en kapsamlı özel sayı olarak karşımızdadır.

Editörlüklerini Ertan Eğribel ile Ufuk Özcan'ın üstlendikleri Sosyoloji Yıllığı, 18. kitabını, 2009'da, iki cilt şeklinde Türkiye'de Toplumbilimlerin Gelişimi - I ve II; 20. kitabını ise 2010'da, yine iki cilt olarak Türk Sosyologları ve Eserleri - I ve II başlıklarıyla yayınlamıştır. ${ }^{1}$ Türk sosyoloji tarihiyle ilgili kimisi yeni kaleme alınmış kimisi de önemli metinlerin yeniden yayınlanmasından müteşekkil bazı önemli makaleleri bu yıllıklarda bulmak mümkündür. Birkaçından bahsedecek olursak; Nilgün Çelebi'nin Türkiye'de Sosyoloji ve Sosyolojinin Türkiye'de Kurumsallaşması makaleleri, Bedri Mermutlu'nun Türkiye'de Ilk Dönem Sosyoloji Eserlerine Toplu Bir Bakış adlı çalışması, Baykan Sezer'in daha önce 1989'da yayınladığı Türk Sosyologlart ve Eserleri I başlığını taşıyan ve Türk sosyolojisinin karakterine yönelik tespitleriyle öne çikan makalesi, Ufuk Özcan'ın kapsamlı ve bütüncül bir tarzda kaleme aldığı Türkiye'de Sosyoloji: Başlıca Akımlar, Dönemler ve Figürler başlıklı makalesi ve son olarak Mehmet Yalvaç'ın Kubbealtı Akademi Mecmuası'nda 1985 yılında yayınlanan İstanbul Üniversitesi Edebiyat Fakültesi'nde Sosyoloji Eğitiminin Tarihçesi (1912-1982) başlıklı oldukça mühim çalışması sayılabilir.

TYB Akademi'nin Eylül 2013 tarihli 9. sayıs1 olan, Türkiye'nin Sosyolojisi: Metinler, Yaklaşımlar, Kişiler Çerçevesinde Türkiye'de Sosyolojinin 100 Yıllık Serüveni özel sayısı ile Sosyoloji Divanı'nın 2014 tarihli 4. sayısı olarak çıkan Asırlık Sosyoloji dergileri de bu kapsamda ele alacağımız süreli yayın özel sayılarıdır. Özellikle Asırlık Sosyoloji içindeki giriş yazıları; İsmail Coşkun'la yapılan röportaj; derginin Muhasebe ve Müzakere bölümünde ele alınan sosyoloji alt disiplinlerinin Türk sosyolojisindeki gelişimlerinin konu edinilmesi ve Suvat Parin' in Literatür Dergisi'nde de ele aldığı sosyoloji kongreleri çalışmasına bir yenisini ekleyerek konuyu geliştirmesi dergide öne çıkanlar arasındadır.

İstanbul Üniversitesi Sosyoloji Dergisi’nin 2014 yılı içinde yayınladığı 28. ve 29. sayılar, Türkiye’de Sosyolojinin 100. Yılı Özel Sayısı başlığında iki cilt-iki sayı şeklinde yayınlanmıştır. 28. sayıda Meşrutiyet dönemine ait sosyolojiyle ilgili ilk sayılabilecek kimi metinler, Çevrimyazılar başlığı altında okuyucuya sunulmuştur, dikkate değerdir. 29. sayıda ise dikkatimizi çeken en önemli yazılardan biri, yine Suvat Parin tarafından kaleme alınan Türkiye'de Yükseköğretimde

1 Aslında her bir yıllık bir kitap olarak çıkmış olsa da, biz burada bu eserleri süreli yayın olarak değerlendirmeyi uygun gördük. 
Sosyoloji Öğretimi Bir Dönemselleştirme Denemesi (1914-2014) başlı̆̆ını taş1yan yazısıdır. Bu sayıda yine Türk sosyolojisinde birçok alt-alanın gelişimiyle ilgili makaleler bulmak mümkündür.

İstanbul Üniversitesi İktisat Fakültesi Metodoloji ve Sosyoloji Araştırmalar1 Merkezi tarafindan yayınlanan Sosyoloji Konferansları Dergisi, 52. sayısını (2015-2) Türkiye’de Sosyolojinin 100 Yulı başlığıyla yayınlamıştır. Sayı editörlüğünü Nevin Güngör Ergan'ın yaptığı dergide, birden çok konu başlığında toplamda 32 makale mevcuttur. Türkiye'de Sosyolojinin Tarihi başlıklı ilk bölümdeki özellikle ilk üç yazı, yazarları ve içerikleriyle tam da burada ele aldığımız mevzuyla birebir ilişkilidir. Korkut Tuna'nın Sosyolojinin Türkiye'ye Gelişinin 100. Yılı Üzerine, Nilgün Çelebi'nin Sosyoloji Tarihimize Kısa Bir Bakış ve H. Bayram Kaçmazoğlu'nun kaleme aldığı Türkiye'de Sosyolojinin 100 Yillık Birikimi Üzerine Bazı Tespitler isimli makaleleri bu sayıda -bizim konumuz bağlamında- öne çıkan çalışmalardır. Bu özel sayıda ayrıca Türkiye'de Sosyoloji Ĕgitimi, Türk Sosyolojisinde Metodoloji, Türkiye'de Sosyolojinin Çalışma Alanları, Türkiye'de Sosyoloji-Siyaset İlişkisi ile Türkiye'de Toplumsal Yapı, Toplumsal Değişme, Toplumsal Problemler ve Sosyoloji üst-başlıkları altında çeşitli makalelere ulaşmak mümkündür. Son olarak yine bu sayıda Bedri Mermutlu'nun Ziya Gökâlp Ille Ilgili Devlet Kayıtları Arasında Bulunan Resmi Belgeler başlıklı belge sunumu da dikkate değerdir.

Bu süreli yayınlar dışında -bu makaleninin yazıldığı süreçte henüz yayınlanmamış olan- Defter Dergisi ile Sosyoloji Yıllığı'nın Türk Sosyolojisi özel sayıları için hazırlık yaptığı bilgisini de buradan paylaşmış olalım.

\section{Bibliyografya Çalışmaları}

Türkiye'de hem sosyolojinin tarihini görebileceğimiz hem de özel olarak Türk sosyoloji tarihi çalışmalarının künyelerini görebileceğimiz üç bibliyografya çalışması mevcuttur.

Bunlardan ilki Mahmut Tezcan tarafından hazırlanan ve 1969 yılında bas1lan Türk Sosyoloji Bibliyografyası (1928-1968) başlıklı çalışmadır. Tezcan bu bibliyografya çalışmasında -bilgisayar teknolojisinin henüz kullanılmadığı bir dönemde, olağanüstü bir gayretle- yeni harflerin kabulünden çalışmanın basım tarihine kadar olan dönem aralığında, Türk sosyolojisiyle ilgili toplamda 6255 tane kaynağın tam künyesini vermiştir. Kitapların yanı sıra 1 Ağustos 1968 tarihine kadarki tüm dergiler de bu kapsamda taranmıştır. Bu devasa çalışmada, Sosyoloji Tarihi bölümündeki kaynakçalar, doğrudan ele aldığımız konuyla ilgilidir.

İkinci bibliyografya çalışması, İstanbul Üniversitesi Sosyoloji Bölümü tarafından yayınlanmıştır. Türkiye'de Sosyolojinin 75. Yılı (1914-1989) başlı̆̆ını taşımakta olan bu bibliyografyada, sadece İ.Ü. Sosyoloji Bölümü yayın ve çalış- 
malarına yer verilmiştir. Kitaplar, dergiler ve tezlerden oluşan bu çalışmada, eski harfle yayınlanmış çalışmaların künyelerini görmek de mümkündür.

Konuyla ilgili elimizdeki son bibliyografya çalışması ise Bedri Mermutlu tarafından 2008 yılında yayınlanan Türk Sosyal Düşünce Bibliyografyası (17291928)'dir. Matbaanın kullanılışından 1928 yeni harflerin kabulüne kadar olan dönemde, metinlerin Arapça harflerle kaleme alındığ 1 bu dönemde, sadece sosyolojiyle ilgili değil tüm sosyal bilimler alanında hangi kitapların yayınlandığını görmek açısından, önemli bir boşluğu doldurmuştur. Kitap, Sezer'in Dil Devrimi Üzerine giriş yazısıyla başlamış, eser künyeleri sosyal bilimler alt-disiplinlerine göre sıralanmıştır. Ayrıca Tezcan'ın bibliyografya çalışmasını da, öncesi olarak tamamlamış görünmektedir.

\section{Makaleler}

$\mathrm{Bu}$ çalışma kapsamında bizzat Türk sosyoloji tarihini kendisine konu edinen makalelerin ilkini, Lütfi Erişçi tarafından kaleme alınan ve 1942 yılında $\dot{I} . \ddot{U}$. Sosyoloji Dergisi'nde yayınlanan Türkiye'de Sosyolojinin Tarihçesi ve Bibliyografyası oluşturacaktır. Konumuzla ilgili elimizdeki en eski tarihli metin olma özelliğini taşıyan bu makale, bu alanda kendisine atıf yapılan ünlenmiş bir yayındır. İçeriği bilgi bakımından oldukça zengindir. İkinci bir makale, Hilmi Ziya Ülken tarafından 1950'de yine İ.Ü. Sosyoloji Dergisi'nde yayınlanan Sociology in Turkey isimli çalışmadır. İngilizce kaleme alınan bu makale Ülken'in, Oslo Milletlerarası Sosyoloji Kongresi'ndeki tebliğidir. 1983 tarihli Cumhuriyet Dönemi Türkiye Ansiklopedisi'nin 8. cildinde yer alan Sosyoloji Çalışmaları bölümünde, Doğan Ergun'un Türkiye'de Cumhuriyet Döneminde Sosyoloji ve Gelişmesi ile Aynur İlyasoğlu'nun Türkiye'de Sosyolojinin Gelişmesi ve Sosyoloji Araştırmaları makaleleri, konu ile ilgili diğer önemli çalışmalardır. ${ }^{2}$ Özellikle İlyasoğlu'nun makalesi, kaynakça olarak da zengindir. -Öyle ki bunlardan bazılarına ulaşamadık.- Tarihi kronolojiden devam edersek; 1986 yılında Oğuz Arı'nın Türkiye'de Sosyoloji Tarihi başlıklı -aslında sempozyum tebliği olan- makalesi, Türkiye'de Sosyal Bilim Araştırmalarının Gelişimi kitabı içinde yayınlanmıştır. Fakat bu makale, ismini kapsayacak derinlikten ve bütünlükten yoksundur. 1996'de yayınlanan Türk Toplumbilimcileri 2 kitabının giriş yazısı olan Zafer Toprak'in Osmanlı'da Toplumbilim'in Doğuşu ${ }^{3}$ makalesi ise, girişteki tarihsel bilgilerden sonra konuyu daha çok Gökalp üzerinden sürdürmektedir.

2 Aynur İlyasoğlu, konuyu ilerleyen yıllarda da ilgi duymuş ve 1998 yılında düzenlenen Sosyal Bilimleri Yeniden Düşünmek Sempozyumu'nda “Türkiye'de Sosyolojinin Tarihini Yazmak: Bir Sorunlaştırma ve Yaklaşım Öneri” başlıklı bir tebliğ sunmuştur. Tam metin için bakınız: Sosyal Bilimleri Yeniden Düşünmek (iç.), Metis Yayınları, İstanbul, 2008, s. 81-97.

3 Toprak'ın bu makalesi, Cumhuriyete Devreden Düşünce Mirası: Tanzimat ve Meşrutiyet'in Birikimi (iç.), Modern Türkiye'de Siyasi Düşünce, Cilt 1, İletişim Yayınları, İstanbul, 2009, s. 310-327'de yeniden yayınlanmıştır. 
Konu ile ilgili yazılan en önemli makalelerden birini, Baykan Sezer'in Türk Sosyologları ve Eserleri I başlıklı çalışması oluşturmaktadır. I. $\ddot{U}$. Sosyoloji Dergisi'nin 1989'daki 1. sayısında yer alan bu hacimli çalışma, aynı zamanda Türk sosyolojisini ve tarihini ele alış biçimiyle de ilgiyi hak etmektedir. Özelde Prens Sabahaddin üzerine yazılan bu makalenin ilk kırk sayfası, tam anlamıyla Türk sosyolojisi okumaları için bir giriştir. Türk toplum düşüncesinin kaynakları ve sosyolojinin ülkemize girişi sırasındaki düşünsel ortamın tartışıldığı bu bölümde Sezer, amacinı "Türk sosyoloji tarihini ana çizgileri ile saptama" olarak belirtmiştir. Bunun için ise ülkemiz sorunları karşısında düşünen ve üreten sosyologları tanımanın önemi aşikârdır.

Cumhuriyet Dönemi Türkiye Ansiklopedisi'nin devam niteliğindeki ciltleri olarak çıkan Yüzyıl Biterken'de Kurtuluş Kayalı'nın kaleme aldığı Türk Sosyolojisinin 80'lerde Yeniden Biçimlenişi başlıklı makalesi, bu bölümdeki son yazımız olacaktır. Fakat Kayalı, çalışmanın odağına 1980 sonrası sosyolojideki gelişmelerden ziyade 1940'lı ve 1960'lı yılların tartışmalarını yerleştirdiğinden, bu makale başlıktaki iddiayı istendik düzeyde karşıllayamamıştır.

Bu bölümü bitirirken İ.Ü. Sosyoloji Dergisi' ni $^{4}$ ve bu dergide belli aralıklarla çıkmaya devam eden konu ile ilgili yayınları hatırlatmak elzemdir. Türk sosyoloji tarihi, kimi vesilelerle ve kimi düşünürlerin özel ilgileriyle sıklıkla bu dergide tartışılmaya devam etmektedir. Recep Ertürk'ün Türk Sosyolojisinin Gelişimi Üzerine; Nilgün Çelebi'nin Sosyolojimizin Tarihini Yazarken başlıklı makaleleri ile özellikle Yücel Bulut'un Türk sosyoloji tarihi ile ilgili birden çok makalesi, bu ilgiyi sıcak tutmaya devam etmektedir. Bu açıdan $\dot{I} . \ddot{U}$. Sosyoloji Dergisi, üzerine aldığg süreklilik misyonunu yerine getirmeyi sürdürmektedir.

$\mathrm{Bu}$ arada künyeleri elimizde olan fakat henüz yazıları bulup inceleme imkânını bulamadığımız birkaç kaynakçadan da bahsetmemek olmaz. Z. Fahri Fındıkoğlu'nun Türklerde İçtimaiyyat Tarihçesi ve Ziya Gökalp, Bizde Sosyoloji ve Birkaç Meselemiz ve İbn-i Haldun ve Türk Sosyolojisi başlıklarını taşıyan makaleleri ile Agâh S. Levent'in Türk Sosyolojisine Bir Bakış ve Erol Güngör'ün Cumhuriyet Devrinde Sosyal İlimler çalışmaları, konu ile ilgili olduklarını düşündüğümüz fakat henüz içeriklerine vakıf olamadığımız metinlerdir. Burada, araştırmacılar için bilgi amaçlı verilmiştir.

4 İstanbul Üniversitesi Sosyoloji Bölümü bünyesindeki bu dergi, yayınını belli aralıklarla gerçekleştirmiştir. İlk olarak İçtimaiyyat Mecmuası ismiyle 1917'de Ziya Gökalp tarafından yayına başlamıştır ve 6 sayı yayınlanmıştır. Dergi daha sonra ikinci dizi olarak Sosyoloji Dergisi adıyla 1941-1942 tarih ve C. 1, S. 1 sayısıyla H. Ziya Ülken'in çabalarıyla 1942 yılında yayınlanmaya başlamış, 1967-1968 tarihli 21-22. sayıdan sonra yayın hayatına ara vermiştir. Sosyoloji Dergisi üçüncü ve hala devam eden yayınıyla birlikte Baykan Sezer'in gayretleriyle 3. Dizi - 1. Sayı 1988-1989 şeklinde yeniden yayın faaliyetine başlamıştır. 


\section{Sonuç}

Sezer (2006), Türk sosyolojisinin kendi gelişmesiyle, geçmişiyle ilgilenmemesine bir neden olarak, bizdeki sosyolojinin Batı'dan aktarılma bir bilim olmasıyla izah eder. Fakat Sezer aynı zamanda Türk sosyologlarının çoğunun Batı'dan etkilenmek, hatta Batı aktarmacıllğı yapmakla birlikte, yine de büyük bir çoğunluğunun Türkiye'nin sorunları önünde düşündüklerini, Batı'dan aktardıkları öğretilerin sınırları içinde de olsa, sorunlarımıza bir açıklama ve çözüm yolları getirmeye çalıştıklarını da ısrarla vurgulamıştır. Bu vurgu, bizim bu çalışmada kendimize konu olarak seçtiğimiz kendi sosyoloji tarihimizden farklı bir şey değildir.

Kendi toplum gerçeğimizi tanıma/bilme, sorunlarımızı anlama/açıklama ve bunlara dönük çözüm önerilerimizi Türk toplumunun çıkarları doğrultusunda belirleyebilmeden müteşekkil Türk sosyolojisi, bu çaba içerisinde yer almış onlarca sosyoloğa ev sahipliği yapmış, yüzyılı aşkın bir serüvendir. Bu serüvenin istikametini koruması ise sürekli olarak kendisini bilmeyle, geçmişini tanımayla canlı tutulabilir. Bu ise Türk sosyoloji tarihi çalışma alanından başka bir şey değildir. Birikimi fark etmek Türk sosyolojisi adına umut vericidir. 


\section{Kaynakça}

75. Yılında Türkiye'de Sosyoloji, ed. İ. Coşkun, İstanbul, Bağlam Yayınları, 1991.

Ar1, O., “Türkiye'de Sosyoloji Tarihi”, Türkiye'de Sosyal Bilim Araştırmalartnın Gelişimi, Ankara, Türk Sosyal Bilimler Derneği Yayınları, 1986.

Eğribel, E. \& Özcan, U., Sosyoloji Yıllığı Kitap 18: Türkiye'de Toplumbilimlerin Gelişimi - I \& II, İstanbul, Kitabevi Yayınc1lık, 2009.

, Sosyoloji Yıllı̆̆ Kitap 20: Türk Sosyologlarl ve Eserleri - I \& II, İstanbul, Kitabevi Yayınc1lık, 2010.

Erişçi, L., "Türkiye'de Sosyolojinin Tarihçesi ve Bibliyografyası", İstanbul Üniversitesi Sosyoloji Dergisi, 1, 1942.

Fındıkoğlu, Z. F., "Türklerde İçtimaiyyat Tarihçesi ve Ziya Gökalp", İ̧̧ Dergisi, 3-4, 1934. Sosyoloji Dergisi, 13-14, 1959.

"Bizde Sosyoloji ve Birkaç Meselemiz", İstanbul Üniversitesi

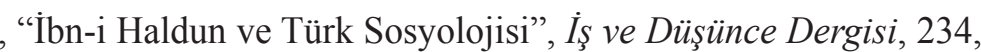
1961.

Güngör, E., Cumhuriyet Devrinde Sosyal İlimler, Kültür ve Sanat Yayınlar1, 1973.

İlyasoğlu, A., "Türkiye'de Sosyolojinin Gelişmesi ve Sosyoloji Araştırmaları", Cumhuriyet Dönemi Türkiye Ansiklopedisi, 8, 1983.

, "Türkiye'de Sosyolojinin Tarihini Yazmak: Bir Sorunsallaştırma ve Yaklaşım Önerisi”, Sosyal Bilimleri Yeniden Düşünmek, İstanbul, Metis Yayınlar1, 2008.

İstanbul Üniversitesi Sosyoloji Dergisi, Türkiye’de Sosyolojinin 100. Yılı Özel Sayısı, 2 cilt, 28-29, 2014.

Kaçmazoğlu, H. B., Türk Sosyoloji Tarihi II: II. Meşrutiyetten Cumhuriyete, Ankara, Anı Yayıncılık, 2003.

c1lik, 2003.

, Türk Sosyoloji Tarihi Üzerine Araştırmalar, Ankara, Anı Yayın-

, Türk Sosyoloji Tarihi I: Önkoşullar, İstanbul, Kitabevi Yayınları, 2010.

, Türk Sosyoloji Tarihi III: Yeni Türkiye'de Sosyolojinin Düşünsel ve Kurumsal Temelleri, İstanbul, Kitabevi Yayınları, 2011.

, Türk Sosyolojinde Temalar, 3 cilt, İstanbul, Doğu Kitabevi, 2012. 
Kayalı, K., "Türk Sosyolojisinin 80'lerde Yeniden Biçimlenişi”, Cumhuriyet Dönemi Türkiye Ansiklopedisi Yüzyll Biterken, 15, 1995. lar1, 2009. , Türk Düşünce Dünyasında Yol İzleri, İstanbul, İletişim Yayın-

Koçer, H. A., Türk Sosyologları I, Ankara, Türk Sosyoloji Araştırmaları Yayınları, 1975.

Levent, A. S., "Türk Sosyolojisine Bir Bakış”, Türk Dili, cilt 13, 151, 1964.

Mardin, Ş., Jön Türklerin Siyasi Fikirleri, İstanbul, İletişim Yayınları, 2008. lar1, 2012. , Yeni Osmanlı Düşüncesinin Doğuşu, İstanbul, İletişim Yayın-

Mermutlu, B., "Türk Sosyal Düşünce Bibliyografyası (1729-1928)", Sosyoloji Yıllığı Kitap 17, İstanbul, Kitabevi Yayınc1lık, 2008.

Milli Kültür Dergisi, Sosyolojimizin Sosyolojisi, 83, 1991.

Sezer, B., "Türk Sosyologları ve Eserleri”, İstanbul Üniversitesi Sosyoloji Dergisi, 3. Dizi, 1, 1989. c1l1k, 2006. , Türk Sosyolojisinin Ana Sorunları, İstanbul, Kızılelma Yayın-

Sosyoloji Divan1 Dergisi, Asırlık Sosyoloji, 4, 2014.

Sosyoloji Konferansları Dergisi, Türkiye'de Sosyolojinin 100 Yllı, 52, 2015.

Tanzimattan Günümüze Türk Düşünürleri, ed. S. H. Bolay, 7 cilt, Ankara, Nobel Yayınc1lık, 2015.

Tezcan M., Türk Sosyoloji Bibliyografyası (1928-1968), Ankara, Başnur Matbaas1, 1969.

Toplumbilim Dergisi, Türk Toplumbilimi Özel Sayısı, 2, 1993.

Toprak, Z., "Osmanlı'da Toplumbilimin Doğuşu”, Türk Toplumbilimcileri 2, ed. E. Kongar, İstanbul, Remzi Kitabevi, 1996.

Tuna, K., Coşkun, İ. \& Tüfekçioğlu H., Türkiye'de Sosyolojinin 75. Yllı (1914-1989), İstanbul, Edebiyat Fakültesi Basımevi, 1989.

Türkiye Araştırmaları Literatür Dergisi, Türk Sosyoloji Tarihi, 11, 2008.

Türkiye'de Sosyoloji: İsimler-Eserler, ed. M. Ç. Özdemir, 2 cilt, Ankara, Phoenix Yayınları, 2008.

Türkiye'de Sosyolojinin Yüzyıllık Serüveni, ed. H. Okçay, İzmir, Duvar Yayınlar1, 2015.

Türk Toplumbilimcileri 1, ed. E. Kongar, İstanbul, Remzi Kitabevi, 1993. 
Türk Toplumbilimcileri 2, ed. E. Kongar, İstanbul, Remzi Kitabevi, 1988.

TYB Akademi Dergisi, Türkiye’nin Sosyolojisi: Metinler, Yaklaşımlar, Kişiler Çerçevesinde Türkiye'de Sosyolojinin 100 Ylllık Serüveni, 9, 2013.

Ülken, H. Z., "Sociology in Turkey”, Istanbul Üniversitesi Sosyoloji Dergisi, 6, 1950 . 2001. , Türkiye'de Çağdaş Düşünce Tarihi, İstanbul, Ülken Yayınları,

Ünsald1, L. \& Geçgin, E., Sosyoloji Tarihi: Dünya'da ve Türkiye'de, Ankara, Heretik Yayınları, 2013. 